\title{
Tumor-to-Tumor Metastasis - a Unique Case of Clear Cell Renal Cell Carcinoma Harboring Metastasis of Adenocarcinoma of Unknown Origin
}

\author{
Metastáza nádoru do nádoru - raritný prípad svetlobunkového \\ renálneho karcinómu obsahujúceho metastázu adenokarcinómu \\ neznámeho pôvodu
}

\author{
Bartoš V. \\ Department of Pathology, Faculty Hospital in Žilina, Slovakia
}

\begin{abstract}
Summary
Background: The tumor-to-tumor metastasis is exclusively rare finding, in which one malignant neoplasia metastasizes to another tumor of different origin. Case: The author describes an 68-year-old woman, who was found to have a solitary tumor in the right kidney, as well as multiple tumor nodules in the liver. She underwent a radical nephrectomy. A histology of lesion in the kidney revealed a conventional clear cell renal cell carcinoma (RCC) harboring multiple metastatic foci of another adenocarcinoma. At that time, there was not possible to reliably specify a primary source. Subsequently, a probatory excision of tumor lesion in the liver was also done. A microscopy confirmed an adenocarcinoma with a similar appearance as found in RCC. Due to unfavourable health condition, a paliative chemotherapy could not be realized and the patient died shortly thereafter. A primary origin of adenocarcinoma remained unclear. Conclusion: A unique case of metastatic adenocarcinoma is described, that was initially diagnosed as an incidental finding within a clear cell RCC of the kidney. Such unexpected feature may represent a great diagnostic challenge for both, pathologist and clinician. From a prognostic point of view, an evidence of intratumoral cancer metastasis within a primary RCC is usually an indicator of disseminated oncologic disease with a poor outcome.
\end{abstract}

Key words

tumor-to-tumor metastasis - donor - recipient - renal cell carcinoma

\section{Súhrn}

Východiská: Metastáza nádoru do nádoru je vel'mi zriedkavý nález, pri ktorom jeden malígny tumor metastázuje do tkaniva iného tumoru odlišného pôvodu. Prípad: Autor opisuje prípad 68-ročnej ženy, ktorá mala verifikovaný solitárny nádor v pravej obličke, ako aj viacpočetné tumorózne noduly $\checkmark$ pečeni. Vykonanú mala radikálnu nefrektómiu. Histologické vyšetrenie nádoru obličky potvrdilo konvenčný svetlobunkový renálny karcinóm (renal cell carcinoma - RCC), ktorý však obsahoval aj metastatické ložiská iného adenokarcinómu. Spolahlivé stanovenie jeho origa nebolo v tom čase možné. Následne bola vykonaná aj probatórna excízia lézie $v$ pečeni. Mikroskopicky išlo o adenokarcinóm podobného vzhladu ako v tkanive RCC. Pre zhoršujúci sa zdravotný stav nemohla mat pacientka realizovanú paliatívnu chemoterapiu a zakrátko exitovala. Pôvod adenokarcinómu ostal neobjasnený. Záver: Opísaný je raritný prípad metastázujúceho adenokarcinómu, ktorý sa prvotne diagnostikoval náhodne $v$ nádorovom tkanive svetlobunkového RCC obličky. Takýto nezvyčajný nález môže predstavovat' velkú diagnostickú dilemu pre patológa aj klinika. Z prognostického hladiska je nález intratumoróznych metastáz v primárnom RCC zvyčajne už prejavom diseminovaného štádia onkologického ochorenia s nepriaznivým klinickým priebehom.
The author would like to thank all physicians, who participated on treatment and clinical management of this patient, and RNDr. Daniela Melová for her outstanding technical assistance.

The author declares he has no potential conflicts of interest concerning drugs, products, or services used in the study.

Autor deklaruje, že $v$ souvislosti s předmětem studie nemá žádné komerční zájmy.

The Editorial Board declares that the manuscript met the ICMJE recommendation for biomedical papers.

Redakční rada potvrzuje, že rukopis práce splnil ICMJE kritéria pro publikace zasílané do biomedicínských časopisů.

$\Xi^{\circ}$

MUDr. PhDr. Vladimír Bartoš,

PhD., MPH

Fakutná nemocnica s poliklinikou

Vojtěcha Spanyola 43

01207 Žilina, Slovensko

e-mail:vladim.bartos@gmail.com

Submitted/Obdrženo: 30. 5. 2018

Accepted/Přijato: 27. 6. 2018

doi: 10.14735/amko2018366

Klúčové slová

metastáza nádoru do nádoru - donor - recipient - karcinóm z renálnych buniek 


\section{Introduction}

The development of multiple primary malignant neoplasms in the same individual is not uncommon. However, the occurrence of one cancer metastatic to another cancer of different origin is extremely rare. The tumor-to-tumor metastasis (TTM) is a long-known phenomenon $[1,2]$ indicating a metastasis of one tumor into the substance of the other. This is in contrast to "collision tumor" which is defined as two neighboring neoplasms that invade one another but without histologic admixture.

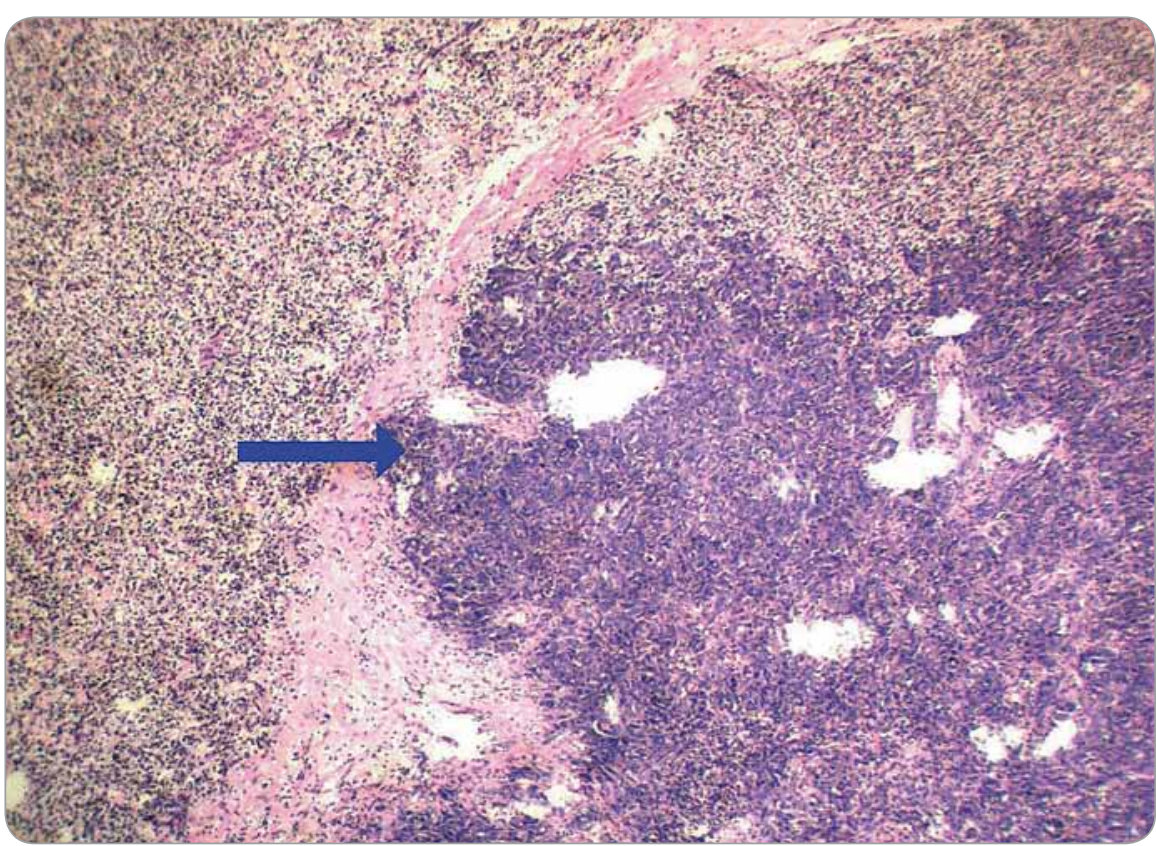

Fig. 1. Conventional clear cell RCC (left and upper part) harboring a metastasis of adenocarcinoma (blue arrow) (hematoxylin \& eosin, magnification $100 \times$ ). $\mathrm{RCC}$ - renal cell carcinoma

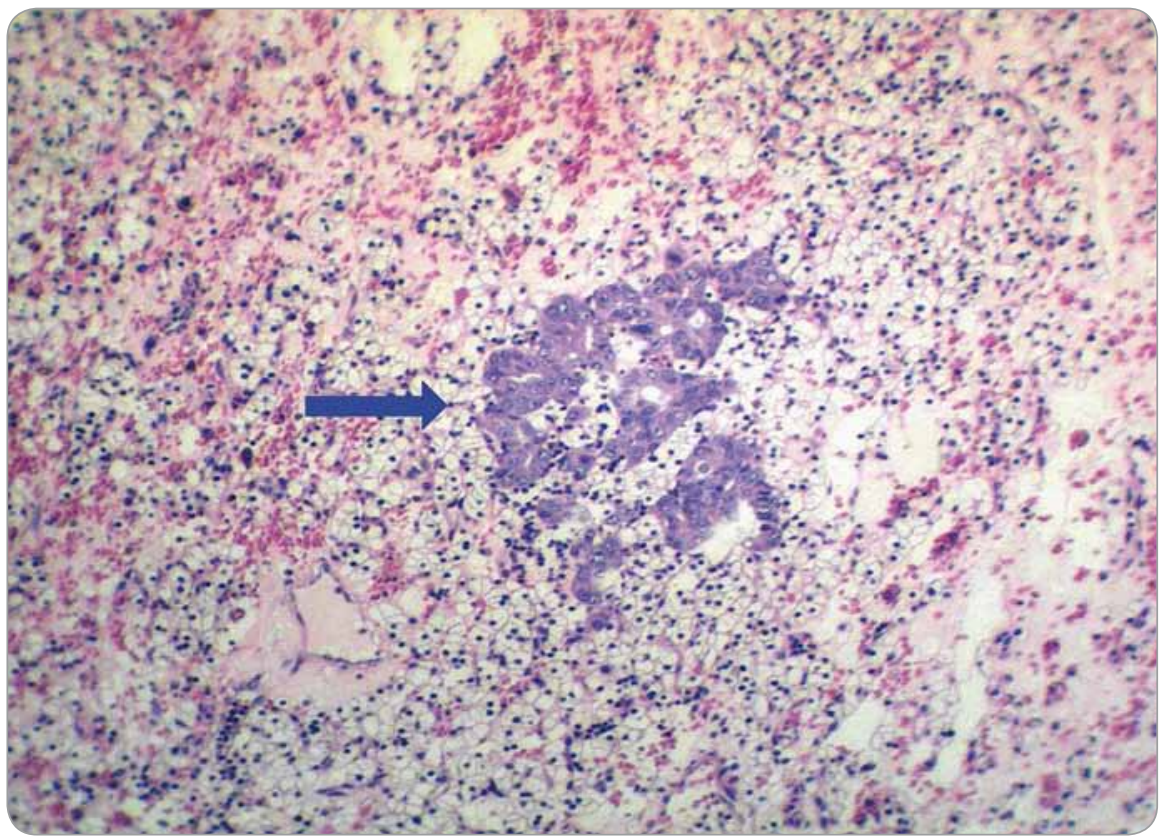

Fig. 2. Small focus of metastatic adenocarcinoma (blue arrow) on the background of clear cell RCC. Metastasis exhibits a typical glandular pattern (hematoxylin \& eosin, magnification 200x).

$\mathrm{RCC}$ - renal cell carcinoma
Renal cell carcinoma (RCC) is the most common type of the kidney cancer in adults [3]. It often develops together with other organ malignancies [4]. It has been previously suggested [4], the TTM might be present in up to $15 \%$ of all individuals with simultaneous RCC and second neoplastic disease. However, a histology-proven TTM in RCC patients is an extraordinary finding in a routine biopsy practice. Herein, I briefly describe a case of adenocarcinoma of unknown origin metastasizing to a clear cell RCC in the kidney. An article is mainly focused on TTM as a peculiar histopathologic entity. As far as I know, this is the first such case published in the Czech and Slovak literature.

\section{Case presentation}

An 68-year-old woman was admitted (March, 2012) to the Department of Urology in the Faculty Hospital in Žilina to provide a core cut biopsy of tumor arising in the right kidney, or (depending on actual health status) to perform a nephrectomy. She suffered from comorbidities (insulin dependent diabetes mellitus, ischaemic heart disease with a history of myocardial infarction, arterial hypertension, chronic renal insufficiency). She had been previously hospitalized at the Department of Internal Medicine in another hospital for overall health deterioration, weakness, anorexia and ascites. Abdominal CT scan revealed a well-demarcated tumor mass in the centre of the right kidney. In addition, multiple tumor nodules in the liver with an infiltration of the inferior vena cava were visible. Furthermore, abdominal and retroperitoneal lympadenopathy, as well as mild splenomegaly were detected. The patient underwent a radical nephrectomy (April, 2012) and biopsy specimen was sent for histopathologic examination. A presumptive clinical diagnosis was a renal cancer with metastases in the liver.

Grossly, the kidney contained a solitary intraparenchymatous tumor that measured $25 \times 22 \times 20 \mathrm{~mm}$. It was yellow-brownish, well-circumscribed and confined to the kidney. Histology revealed a conventional clear cell RCC, 
Fuhrman grade 1. More interestingly, a tumor tissue also contained multiple foci (up to $5 \mathrm{~mm}$ ) of moderate to poorly differentiated adenocarcinoma of another origin. It grew predominatly in a solid fashion (Fig. 1), but in some areas, an apparent glandular pattern was visible (Fig. 2). These metastatic aggregates were clearly highlighted by immunohistochemical expression of cytokeratin 7 (Fig. 3), high molecular weight cytokeratin and carcinoembryonic antigen. A complex immunohistochemistry of both malignancies is summarized in Tab. 1. No metastatic tumor deposits were found in the surrounding non-neoplastic renal tissue. Since RCC was well differentiated and confined to the kidney (stage pT1a), it did not require further treatment. However, from a prognostic point of view, much more important and crucial for next managment was metastasis of adenocarcinoma. Since it represented the first and incidental diagnosis, at that time, there was not possible to reliably specify a primary origin. Based upon the immunophenotype, the pathologist excluded a colorectal origin. However, he pointed out that a negativity for estrogen and progesterone receptors could not exclude a gynecologic source. After receiving a biopsy report, the patient has been referred (May, 2012) to oncodispensary care. Because she come from another district and was managed in her permanent residency region, I had only sparce information about her further clinical workup. I was able to retrieve the following data. At first, the oncologist proposed to perform a probatory biopsy of the liver to elucidate character of multiple tumors. A surgical excision of the lesion was done (June, 2012). The microscopic examination confirmed a moderately to poorly differentiated adenocarcinoma arranged in solid, tubular and trabecular patterns. Immunohistochemically, it showed a strong expression for cytokeratin 7 and a focal expression for cytokeratin 20. The lesion resembled a metastatic adenocarcinoma which had been found in RCC in previous biopsy. The pathologist suggested a primary origin in the pancreatobiliary

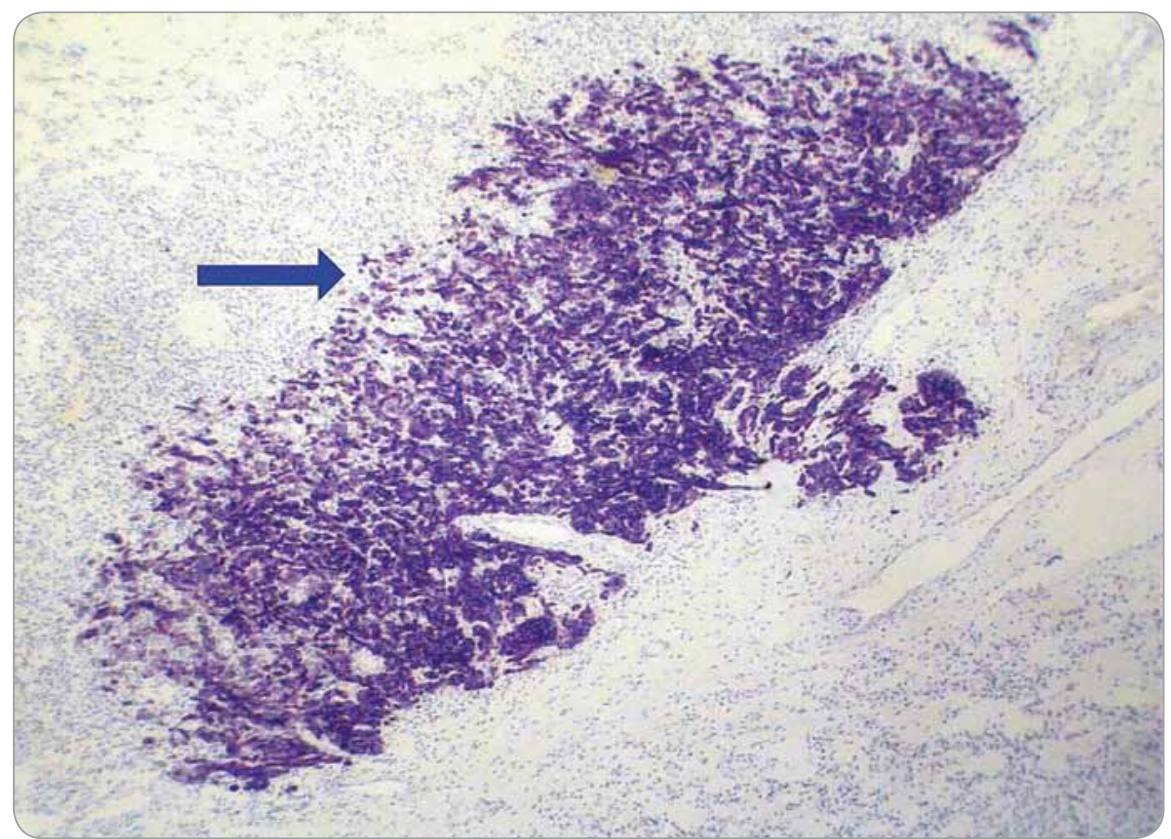

Fig. 3. Strong immunoreactivity of metastatic adenocarcinoma for cytokeratin 7 (blue arrow), while surrounding RCC tissue is negative (clone OV-TL 12/30, magnification 100x).

RCC - renal cell carcinoma

Tab. 1. List of antibodies and results of immunostaining in both tumor components.

\begin{tabular}{|l|c|c|c|}
\hline Marker & Clone & RCC & Adenocarcinoma \\
\hline RCC antigen & SPM 314 & positive & negative \\
\hline EMA & E 29 & positive & positive \\
\hline vimentin & V 9 & positive & positive \\
\hline cytokeratin 7 & OV-TL 12/30 & negative & positive \\
\hline cytokeratin 20 & Ks20.8 & negative & negative \\
\hline HMWCK & 34BE12 & negative & positive \\
\hline polyclonal CEA & polyclonal rabbit & negative & positive \\
\hline monoclonal CEA & II-7 & negative & positive \\
\hline p63 & DAK-P63 & negative & negative \\
\hline estrogen receptor & EP1 & negative & negative \\
\hline progesterone receptor & PgR 636 & negative & negative \\
\hline
\end{tabular}

RCC - renal cell carcinoma, EMA - epithelial membrane antigen, HMWCK - high molecular weight cytokeratin, CEA - carcinoembryonic antigen

system. Subsequently, a systemic paliative chemotherapy was planned, but it could not be actually realize due to renal failure. A therapeutic strategy was continued only on the basis of best supportive care. Despite this treatment, the patient's health condition deteriorated and she died a few days later (July, 2012). A primary origin of adenocarcinoma remained unclear.

\section{Discussion}

Although synchronous or metachronous coexistence of two or more primary neoplasms in the same patient is quite common, the TTM is a very rare pheno- 
Tab. 2. Summary of clinicopathologic findings of the patients extracted from the published case reports.

\begin{tabular}{|c|c|c|c|c|}
\hline Ref. & Sex & Age & Donor & Recipient \\
\hline [1] & M & 58 & adenocarcinoma of the lung & clear cell RCC \\
\hline [1] & M & 65 & adenocarcinoma of the lung & clear cell RCC \\
\hline [1] & M & 72 & adenocarcinoma of the prostate & clear cell RCC \\
\hline [1] & M & 56 & adenocarcinoma of the prostate & clear cell RCC \\
\hline [12] & M & 72 & papillary carcinoma of the thyroid gland & clear cell RCC \\
\hline [7] & $\mathrm{F}$ & 43 & ductal carcinoma of the breast & clear cell RCC \\
\hline [10] & $\mathrm{F}$ & 82 & colorectal adenocarcinoma & $\begin{array}{l}\text { chromo- } \\
\text { phobe RCC }\end{array}$ \\
\hline [11] & M & 81 & adenocarcinoma of the prostate & clear cell RCC \\
\hline [13] & M & 62 & adenocarcinoma of the prostate & clear cell RCC \\
\hline [14] & $\mathrm{F}$ & 75 & signet-ring cell carcinoma of the stomach & clear cell RCC \\
\hline [8] & $\mathrm{F}$ & 97 & adenocarcinoma of the lung & clear cell RCC \\
\hline [9] & $\mathrm{F}$ & 65 & adenocarcinoma of the lung & clear cell RCC \\
\hline [15] & M & 57 & adenocarcinoma of the lung & clear cell RCC \\
\hline [16] & $\mathrm{F}$ & 75 & ductal carcinoma of the breast & clear cell RCC \\
\hline [17] & $\mathrm{F}$ & 67 & adenocarcinoma of the lung & clear cell RCC \\
\hline [18] & M & 62 & small cell carcinoma of the lung & clear cell RCC \\
\hline [19] & M & 56 & $\begin{array}{l}\text { basaloid squamous cell carcinoma } \\
\text { of the tonsil }\end{array}$ & clear cell RCC \\
\hline [6] & $\mathrm{F}$ & 42 & micropapillary carcinoma of the breast & $\begin{array}{l}\text { unclassified } \\
\text { RCC }\end{array}$ \\
\hline [20] & $\mathrm{F}$ & 64 & ductal carcinoma of the breast & clear cell RCC \\
\hline $\begin{array}{l}\text { this } \\
\text { case }\end{array}$ & $\mathrm{F}$ & 68 & unknown origin & clear ce \\
\hline
\end{tabular}

RCC - renal cell carcinoma common recipient among malignant neoplasms [5-11]. The donor tumor is most often the carcinoma of the lung [5-11]. The reason for the high incidence of clear cell RCC as a recipient for TTM is unclear, however, both theories described previously seem to be involved. First, as the clear cell RCC contains a large amount of glycogen and lipids, this may provide a nutrientrich microenvironment for homing of metastatic tumor cells $[7,8,10,11]$. Second, because it is typically hypervascular and the kidney per se receive a significant blood flow, a large number of circulating neoplastic cells shed from a donor cancer may enter the tumor $[7,8,10,11]$.

To the best of my knowledge, only a few dozen case reports addressing cancer metastasis to primary RCC has been documented in the literature. I have reviewed 19 cases, which are briefly summarized in Tab. 2 [1,6-20], including this present case. The mean age of the patients was 66 years (range 42-97 years). The proportion of males and females was equal. Except for two RCCs, all the others were made up of the conventional clear cell subtype. The most common donor tumor was a carcinoma of the lung, followed by breast and prostatic cancer. Of note, while primary RCCs were usually confined to the kidney and did not metastasize, the vast majority of the second malignancy exhibited widespread metastases.

\section{Conclusion}

A unique case of metastatic adenocarcinoma is described, that was initially diagnosed as an incidental finding within a clear cell RCC of the kidney. Such unexpected feature may represent a great diagnostic challenge for both, pathologist and clinician. From a prognostic point of view, an evidence of intratumoral cancer metastasis within a primary RCC is usually an indicator of disseminated oncologic disease with a poor outcome.

\section{References}

1. Rabson SM, Stier PL, Baumgartner JC et al. Metastasis of cancer to cancer. Am J Clin Pathol 1954; 24(5): 572-579. doi: 10.1093/ajcp/24.5.572. 
2. Campbell LV Jr, Gilbert E. Metastases of cancer to cancer. Cancer 1968; 22(3): 635-643.

3. Majerčák J, Ondrušová M, Ondruš D. Súčasný pohl'ad na diagnostiku a liečbu karcinómu obličky. Klin Onkol 2017 30(3): 175-181. doi:10.14735/amko2017175.

4. Poprach A, Lakomý R, Selingerová I et al. Epidemiologická a klinicko-patologická charakteristika pacientů s renálním karcinomem: analýzy 544 prípadů z jednoho centra. Klin Onkol 2013; 26(2): 114-123.

5. Sella A, Ro JY. Renal cell cancer: best recipient of tumorto-tumor metastasis. Urology 1987; 30(1): 35-38.

6. Gazel E, Yalcin S, Kaya E et al. Metastasis of breast cancer to renal cell carcinoma: a rare case of tumor-to-tumor metastasis (TTM). Clin Surg 2018; 3: 1935

7. Huo Z, Gao Y, Yu Z et al. Metastasis of breast cancer to renal cancer: report of a rare case. Int J Clin Exp Pathol 2015; 8(11): 15417-15421.

8. Sawada T, Takahashi H, Hasatani K et al. Tumor-to-tumor metastasis: report of an autopsy case of lung adenocarcinoma metastasizing to renal cell carcinoma. Inter Med 2009: 48(17): 1525-1529.

9. Granville LA, Ostrowski ML, Truong LD et al. Pathologic quiz case. Unusual morphology in an otherwise classic renal cell carcinoma. Arch Pathol Lab Med 2005; 129(2): e49-e50 doi: 10.1043/1543-2165(2005)129<e49:PQC > 2.0.CO;2.

10. Shin T, Kan T, Sato F et al. Tumor-to-tumor metastasis to chromophobe renal cell carcinoma: a first report. Case Rep Urol 2011; 2011: 520839. doi: 10.1155/2011/520839.

11. Arceño JA, Mendoza JS, Castillo JC et al. Prostatic adenocarcinoma ( $\mathrm{PCa}$ ) metastasizing to renal cell carcinoma (RCC) with periureteral tumor deposit: A case of tumorto-tumor metastasis (TTM). Hum Pathol 2017; 8: 27-30. doi: 10.1016/j.ehpc.2017.01.002.

12. Song JS, Taylor SM, Trites J et al. Tumor-to-tumor metastases: papillary thyroid carcinoma into a clear cell rena cell carcinoma. J Otolaryngol Head Neck Surg 2017; 46(1): 17. doi: 10.1186/s40463-017-0193-3.

13. Inatomi $H$, Yamada $Y$, Okamura T. A case of prostate carcinoma metastasizing to renal cell carcinoma. Int J Urol 1996; 3(2): 155-157.

14. Sakai Y, Kanomata N, Kajimoto K et al. Signet-ring cell carcinoma of the stomach metastasizing to renal cell carcinoma: a case report and review of the literature. Kobe J Med Sci 2010; 55(6): E122-E131.

15. Aggarwal N, Amin RM, Chung D et al. Tumor-to-tumor metastasis: case report of a pulmonary adenocarcinoma metastatic to a clear cell renal cell carcinoma. Pathol Res Pract 2012; 208(1): 50-52. doi: 10.1016/j.prp.2011.10. 003.

16. Val-Bernal JF, Villoria F, Pérez-Expósito MA. Concurrent angiomyolipomas and renal cell carcinoma harboring metastatic foci of mammary carcinoma in the same kidney: an incidental autopsy finding in a patient with a follow-up of thirty years. Ann Diagn Pathol 2001; 5(5): 293-299. doi: 10.1053/adpa.2001.27920.

17. Takiguchi Y, Kasamatsu N, Hashizume I et al. An autopsy case of lung cancer metastasizing to renal cell cancer and rectal villous adenoma. Nihon Kyobu Shikkan Gakkai Zasshi 1994; 32(12): 1204-1208.

18. Hibi H, Itoh K, Ono K et al. A case of metastasis of lung cancer to renal cell carcinoma. Nihon Hinyokika Gakkai Zasshi 1991; 82(3): 488-491.

19. Khurana KK, Powers CN. Basaloid squamous carcinoma metastatic to renal-cell carcinoma: fine-needle aspiration cytology of tumor-to-tumor metastasis. Diagn Cytopathol 1997; 17(5): 379-382

20. Möller MG, Gribbin T, Ebrom S et al. Breast cancer metastatic to renal cell carcinoma. Surgery 2006; 139(4): 577-579. doi: 10.1016/j.surg.2005.10.016. 